\title{
Airman
}

\author{
Jurnal Teknik dan Keselamatan Transportasi
}

\section{Implementasi Kurikulum Pendidikan pada Program Studi Lalu Lintas Udara di Politeknik Penerbangan Makassar (Studi Evaluasi Materi Aerodrome Control Procedures)}

\section{Implementation of the Education Curriculum in the Air Traffic Controller Study Program at Makassar Aviation Polytechnic (Aerodrome Control Procedures Material Evaluation Study)}

\author{
Nining Idyaningsih ${ }^{1}$, Rusman $^{2}$, Dhian Supardam ${ }^{3}$ \\ ondeng77@gmail.com, rusmanatkpmks@gmail.com, dhians14.dd@gmail.com
}

Politeknik Penerbangan Makassar

\begin{abstract}
ABSTRAK
Perguruan tinggi sebagai salah satu bentuk satuan pendidikan yang memberikan pengetahuan akademik dan atau profesional harus mampu memberikan layanan dan menghasilkan keluaran yang berkualitas melalui program-program strategis. Lulusannya diharapkan mampu mengatasi masalah yang ada. Banyak faktor yang dapat mempengaruhi mutu perguruan tinggi seperti dosen, sarana prasarana, kurikulum dan proses belajar mengajar, serta sistem penilaian. Begitu pula parameter kualitas pendidikannya, baik dilihat dari segi input, process, product, maupun outcome selalu berubah dari waktu ke waktu. Tujuan penelitian ini mengetahui apa input, transformasi, output dan outcome dari hasil pelaksanaan kurikulum di program studi Manajemen Lalu Lintas Udara. Data lebih erat kaitannya dengan masalah tertentu, karena data dikumpulkan melalui wawancara dalam bentuk tanya jawab langsung kepada pemberi informasi yang mewakili lulusan dan pengajar, serta observasi dan analisis data selanjutnya. Metode analisis penelitian ini adalah deskriptif dan kualitatif.
\end{abstract}

Kata kunci : Implementasi Kurikulum Pendidikan; Perguruan Tinggi Vokasi

\begin{abstract}
Higher education as a form of an educational unit that provides academic and or professional knowledge must be able to provide services and produce quality outputs through strategic programs. Graduates are expected to be able to overcome existing problems. Many factors can affect the quality of higher education such as lecturers, infrastructure, curriculum and teaching, and learning processes, as well as the assessment system. Likewise, the parameters of the quality of education, both in terms of input, process, product, and outcome always change from time to time. The purpose of this study is to find out what inputs, transformations, outputs, and outcomes are from the results of implementing the curriculum in the Air Traffic Management study program. Data is more closely related to certain problems because data is collected through interviews in the form of direct questions and answers to informants representing graduates and teachers, as well as observation and subsequent data analysis. The analytical method of this research is descriptive and qualitative.
\end{abstract}

Keywords: Implementation of the Education Curriculum; Vocational Higher Education 


\section{PENDAHULUAN}

Seiring dengan perkembangan sektor pendidikan, pencapaian tujuan yang sempurna dan akhir akan terus berkembang. Hal ini terjadi karena konteks pendidikan terus berubah dan tidak pernah konstan dalam menanggapi perubahan masyarakat, ilmu pengetahuan dan teknologi. Terlebih lagi, di era informasi sekarang ini, keterbukaan hampir di setiap aspek kehidupan dan sistem manusia tidak bisa lagi dicegah dengan kekerasan. Ini berdampak pada penuaan yang cepat dari kebijakan dan praktik pendidikan (Jalal \& Dedi, 2001).

Begitu pula dengan parameter mutu pendidikan yang berubah dari waktu ke waktu, baik dari segi input, proses, produk maupun outcome (Engoswara, 1987; Arikunto, 2012). Oleh karena itu, kualitas pendidikan nasional melalui reformasi yang akuntabel kepada para pemangku kepentingan agar kita di bidang pendidikan dapat mempersiapkan generasi penerus bangsa yang memiliki keunggulan kompetitif dalam menjawab dan memecahkan tantangan masa depan negara (Nawawi, 1989; Tilaar, 2008). Keberhasilan negara dalam mengatasi tantangan masa depan sangat bergantung pada keberhasilan perbaikan dan pembaruan perkembangan saat ini di sektor pendidikan.

Perguruan Tinggi sebagai satuan pendidikan yang memberikan ilmu akademik dan/atau profesional harus mampu melayani dan mencapai hasil yang berkualitas melalui program-program strategis. Lulusan diharapkan mampu menyelesaikan permasalahan yanga ada. Ada beberapa faktor yang dapat mempengaruhi mutu perguruan tinggi seperti dosen, sarana prasarana, kurikulum dan proses belajar mengajar, serta sistem penilaian (Suwandi, 1999; Purwadi, 2003; Nana, 2005). Walaupun demikian, faktor dosen tidak dapat disamakan dengan faktor-faktor lainnya. Dosen adalah sumber daya manusia yang diharapkan mampu mengerahkan kemampuannya dan mendayagunakan faktor-faktor lainnya sehingga tercipta proses belajar yang bermutu. Tanpa mengabaikan peran faktor-faktor lain, dosen dapat dianggap sebagai faktor utama yang paling menentukan terhadap meningkatnya mutu perguruan tinggi.

Politeknik Penebangan Makassar sebagai salah satu institusi perguruan tinggi di Indonesia, merupakan pendidikan tinggi di bawah Kementerian Perhubungan Indonesia, dengan tugas pokok melaksanakan pendidikan profesional program diploma bidang keahlian teknik dan keselamatan penerbangan.

Terkhusus pada program studi Manajemen Lalu Lintas Udara Politeknik Penebangan (POLTEKBANG) Makassar merupakan bidang studi yang bertujuan untuk menghasilkan tenaga didik yang ahli dan terampil dalam memandu dan me-manage lalu-lintas udara (air traffic) dengan disiplin dan dedikasi yang tinggi.

Tujuan yang diharapkan dapat tercapai dari penelitian ini adalah

1. Mengetahui apa input dari program studi Manajemen Lalu Lintas Udara

2. Mengetahui apa transformasi dalam pelaksanaan kurikulum pada program studi Manajemen Lalu Lintas Penerbangan

3. Mengetahui output dari hasil pelaksanaan kurikulum di program studi Manajemen Lalu Lintas Udara.

4. Mengetahui outcome dari hasil pelaksanaan kurikulum di Program studi lalu lintas udara Politeknik Penerbangan Makassar

\section{METODE}

\section{Jenis penelitian}

a. Dari segi tujuan merupakan penelitian lapangan tentang implementasi kurikulum pendidkan pada program studi lalu lintas udara

b. Dari segi pendekatan Berdasarkan pada pendekatan teori yang berpedoman pada buku-buku referensi yang didapat dari pendidikan yang berhubungan dengan permasalahan ini.

c. Dari segi bidang ilmu, Penelitian yang terkait dengan implementasi kurikulum pendidkan pada program studi lalu lintas udara

d. Dari segi tempat, Penelitian lapangan di Politeknik Penerbangan (Poltekbang) Makassar.

e. Dari segi variabel yang digunakan yaitu Penelitian deskriptif yang ada di Politeknik Penerbangan (Poltekbang) Makassar.

\section{Waktu dan Lokasi penelitian}

Waktu penelitian di mulai dari April sampai dengan Oktober 2021 Lokasi penelitian Politeknik Penerbangan Makassar. 


\section{Teknik Analisa Data}

Metode analisis penelitian ini adalah deskriptif dan kualitatif. Teknik analisis deskriptif kualitatif adalah metode pengumpulan data yang ditampilkan dalam bentuk kata-kata atau simbol-simbol yang disusun menjadi teks yang diperluas melalui observasi, survei, survei, wawancara, dan penelusuran literatur. Metode deskripsi kualitatif tentu saja lebih menekankan pada deskripsi apa adanya, sehingga menurut sifatnya perlu terlibat langsung di lapangan pada saat melakukan observasi (Nazir, 2005; Sugiyono, 2008; Riduwan, 2009). Dalam penyusunan penelitian di Politeknik Penerbangan Makassar, penulis menggunakan metode deskriptif kualitatif, yaitu metode pengumpulan data yang mengarah pada keterlibatan langsung di lapangan

\section{HASIL DAN PEMBAHASAN}

a. Aspek Masukan (Input)

Input adalah bahan mentah yang yang dimasukkan ke dalam transformasi. Di dunia sekolah, bahan mentah mengacu pada calon taruna yang akan mulai sekolah. Sebelum mendaftar di Sekolah Poltekbang Makassar, calon calon taruna akan diuji kemampuannya terlebih dahulu. Dengan penilaian itu ingin diketahui apakah kelak ia akan mampu mengikuti pelajaran dan melaksanakan tugas-tugas yang akan diberikan kepadanya.

Efektivitas penerapan sistem rekrutmen taruna baru untuk menghasilkan taruna yang berkualitas adalah tercapainya kriteria seleksi, jumlah pelamar, persentase pelamar dalam kapasitas, dan persentase pelamar yang mendaftar.

Rekrutmen taruna Poltekbang Makassar dilakukan oleh Panitia Penerimaan Taruna Baru yang dibentuk setiap tahun melalui Surat Keputusan BPSDM Kementrian Perhubungan Indonesia.. Sedangkan Poltekbang Makassar dalam proses penerimaan sipencatar tersebut sebagai fasilitator untuk menunjang pelaksanaan penerimaan sipencatar tersebut. Kegiatan penerimaan taruna baru diarahkan pada kegiatan sosialisasi kedaerah, pemasangan spanduk, penyebaran brosur, iklan layanan masyarakat di media elektronik dan pengiriman surat himbauan ke
Dinas/Instansi-instansi pemerintah dan Sekolah-sekolah menengah SMU/SMK/MA, dan lain-lain.

Evaluasi hasil seleksi bertujuan untuk memperoleh informasi tentang kualitas calon Taruna yang akan mengikuti program Studi yang ada di lingkungan Politeknik Makassar.

Berdasarkan hasil wawancara bahwa pada proses penerimaan sipencatar khususnya pada Poltekbang Makassar, masih perlu dilakukan pembenahan terutama dalam hal konsistensi implementor panitia penerimaan sipencatar terhadap mekanisme sebagaimana yang telah ditetapkan oleh Badan Pengembangan Sumber Daya Manusia Kementrian Perhubungan Republik Indonesia.

b. Aspek Transformasi

Yang dimaksud dengan transformasi dalam hal ini ialah mesin yang bertugas mengubah bahan mentah menjadi bahan jadi yang diharapkan, yang dalam hal ini adalah taruna lulusan sekolah Politeknik Penerbangan Makassar.

Adapun unsur-unsur yang berfungsi sebagai faktor penentu dalam kegiatan implementasi kurikulum antara lain diuraikan sebagai berikut (1) Taruna (2) Dosen (3) Waktu pembelajaran.

Adapun kuisioner yang diberikan kepada dosen dan alumni dapat dilihat pada table berikut ini.

Beri tanda $\sqrt{ }$ jawaban yang anda anggap sesuai pada jawaban yang tersedia

Identitas Koresponden

1. Nama

2. Umur

3. Pendidikan

TABEL 1.

KUISIONER UNTUK MATERI TEORI AERODROME CONTROL PROCEDURES

\begin{tabular}{|c|l|c|c|c|}
\hline NO & \multicolumn{1}{|c|}{$\begin{array}{l}\text { MATERI PELAJARAN } \\
\text { TEORI }\end{array}$} & \multicolumn{3}{|c|}{ TEORI } \\
\hline MKK 1: ADC 1 & K & C & B \\
\hline 1 & $\begin{array}{l}\text { Physical characteristic of } \\
\text { Aerodrome; }\end{array}$ & & & \\
\hline 2 & $\begin{array}{l}\text { Visual ground aids and } \\
\text { emergency lighting; }\end{array}$ & & & \\
\hline 3 & Aerodromes location & & & \\
\hline
\end{tabular}




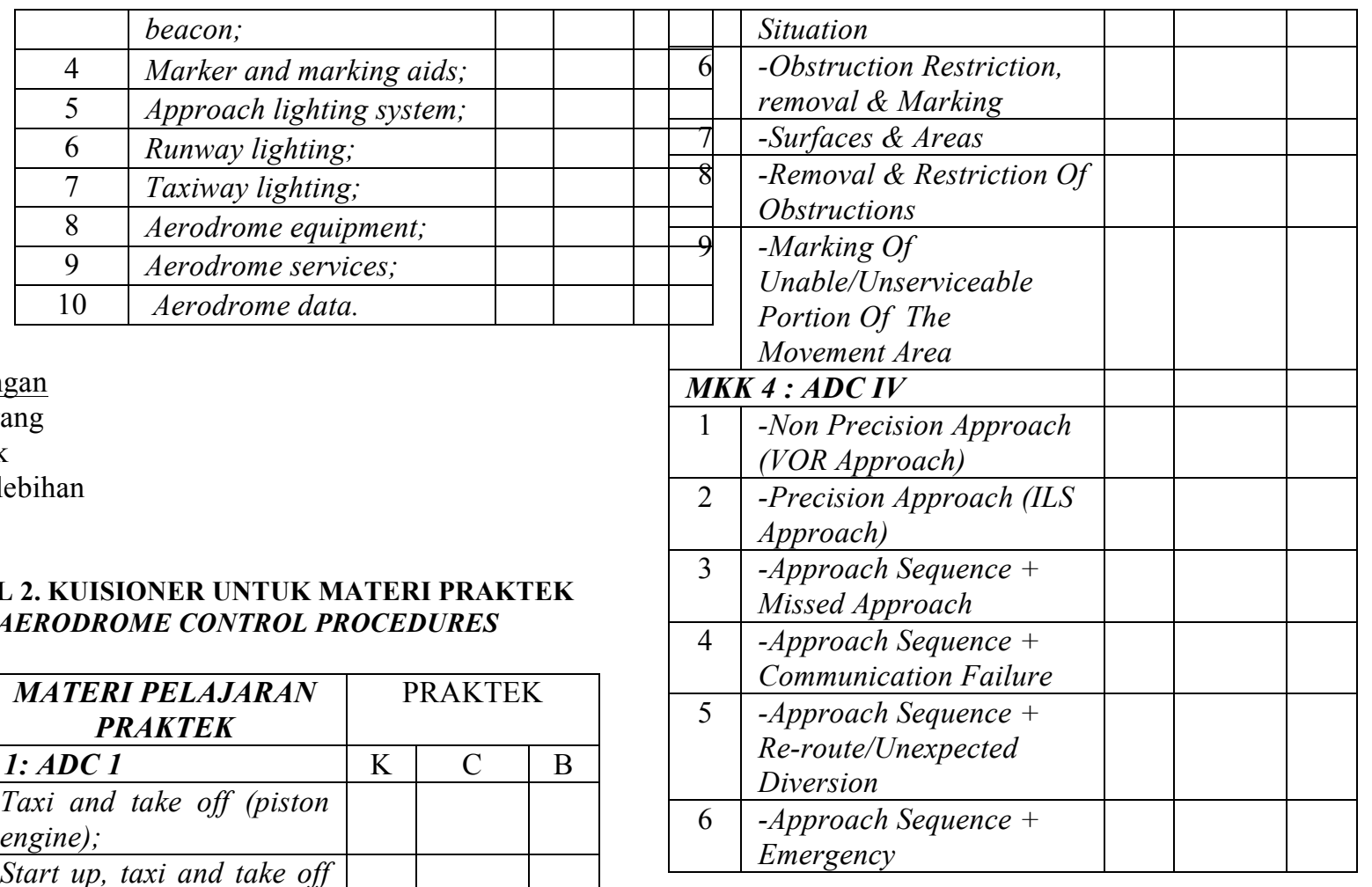

$\underline{\text { Keterangan }}$

$\mathrm{K}:$ Kurang

$\mathrm{C}:$ Baik

B ; Berlebihan

TABEL 2. KUISIONER UNTUK MATERI PRAKTEK AERODROME CONTROL PROCEDURES

\begin{tabular}{|c|c|c|c|c|}
\hline NO & $\begin{array}{c}\text { MATERI PELAJARAN } \\
\text { PRAKTEK }\end{array}$ & \multicolumn{3}{|c|}{ PRAKTEK } \\
\hline \multicolumn{2}{|c|}{ MKK 1: ADC 1} & $\mathrm{~K}$ & $\mathrm{C}$ & $\mathrm{B}$ \\
\hline 1 & $\begin{array}{l}\text { Taxi and take off (piston } \\
\text { engine); }\end{array}$ & & & \\
\hline 2 & $\begin{array}{l}\text { Start up, taxi and take off } \\
\text { (Piston \& Turbo engine); }\end{array}$ & & & \\
\hline 3 & $\begin{array}{l}\text { Landing instruction, } \\
\text { sequence arrangement; }\end{array}$ & & & \\
\hline 4 & $\begin{array}{l}\text { Departure and arrival } \\
\text { procedures }+ \text { traffic info; }\end{array}$ & & & \\
\hline 5 & $\begin{array}{l}\text { Idem }+ \text { Vehicle }+ \\
\text { helicopter operations. }\end{array}$ & & & \\
\hline \multicolumn{2}{|c|}{ MKK $2: A D C I I$} & & & \\
\hline 1 & $\begin{array}{l}\text { Taxi and take off (piston } \\
\text { engine); }\end{array}$ & & & \\
\hline 2 & $\begin{array}{l}\text { Start up, taxi and take off } \\
\text { (Piston \& Turbo engine); }\end{array}$ & & & \\
\hline 3 & $\begin{array}{l}\text { Landing instruction, } \\
\text { sequence arrangement; }\end{array}$ & & & \\
\hline 4 & $\begin{array}{l}\text { Departure and arrival } \\
\text { procedures }+ \text { traffic info; }\end{array}$ & & & \\
\hline 5 & Idem + local flight; & & & \\
\hline 6 & $\begin{array}{l}\text { Idem + unexpected traffic } \\
+ \text { overflying; }\end{array}$ & & & \\
\hline 7 & $\begin{array}{l}\text { Idem + communication } \\
\text { failure; }\end{array}$ & & & \\
\hline 8 & $\begin{array}{l}\text { Idem }+ \text { dep/IFR }+ \text { multi } \\
\text { runways operation; }\end{array}$ & & & \\
\hline 9 & $\begin{array}{l}\text { Idem }+ \text { arr/IFR } \\
\text { (instrument approach). }\end{array}$ & & & \\
\hline \multicolumn{2}{|c|}{ MKK $3: A D C I I I$} & & & \\
\hline 1 & $\begin{array}{l}\text {-Missed Approach }+ \\
\text { Special VFR Operation }\end{array}$ & & & \\
\hline 2 & -General Procedures & & & \\
\hline 3 & $\begin{array}{l}\text {-Idem }+ \text { Change Of } \\
\text { Runway }\end{array}$ & & & \\
\hline 4 & $\begin{array}{l}\text {-Idem }+ \text { Urgency Of } \\
\text { Runway }\end{array}$ & & & \\
\hline 5 & -Idem + Emergency & & & \\
\hline
\end{tabular}

Dari hasil wawancara oleh para alumni ATKP Makassar, terdapat beberapa sub pembahasan yang dianggap kurang pada mata kuliah ini. Sub pembahasan tersebut adalah sebagai berikut: untuk teori Marker and marking aids, approach lighting system, Departing from paralel runway, mach Number Technique sedangkan untuk praktek missed approach + special VFR operation, obstruction rectriction, removal and marking, Surfaces and area, Marking of unable, bearing from aircraft and twilight.

Berdasarkan hal tersebut dapat disimpulkan bahwa pada teori yang kurang perlu penambahan waktu dan pengenalan alat agar taruna dapat mengetahui dan mengenal lebih mendalam mengenai materi tersebut.

Adapun materi kuliah praktikum yang di evaluasi dalam hal ini adalah praktikum mata kuliah Approach Control Service (APP) dan Aerodrome Control Service (Tower). Pada praktikum Approach Control Service (APP) terdapat beberapa yang dianggap kurang yaitu pada sub pembahasan missed approach + special VFR operation, obstruction rectriction, removal and marking, Surfaces and area, Marking of unable, bearing from aircraft and twilight.

\section{c. Aspek Output}

Dalam upaya peningkatan mutu lulusan, Politeknik Penerbangan Makassar 
maupun program studi yang ada selalu mengevaluasi lulusan dengan memberikan quesioner baik itu kepada alumni maupun pengguna lulusan. Quesioner tersebut dilakukan evalusi dan kajian sebagai input dan menjadi program kerja dalam pengembangkan mutu serta kualitas pendidikan. Selain itu, Politeknik Penerbangan Makassar sudah membuat suatu Quality Assurance Management dengan Job Discription yang sudah ada.

Kualitas lulusan dilihat dari aspek IPK dan lama akademik cukup baik, dan usaha untuk mendapatkan lulusan berkualitas dalam aspek proses pembelajaran, Seorang taruna harus mampu menyelesaikan akademik dengan tepat waktu dan tingkat IPK yang memuaskan. Dengan demikian lulusan akan selalu mengerti arah perkembangan IPTEK terbaru sehingga mampu berkomunikasi di dunia nasional maupun internasional.

Sedangkan aspek output, ditinjau dari segi kebutuhan (need assesment) oleh para pengguna (user) air traffict controller pada beberapa Bandar Udara di Indonesia, bahwa kuota lulusan sipencatar khususnya pada program studi lalu lintas udara jumlahnya masih kurang

\section{d. Aspek Outcome / Umpan Balik}

Setelah taruna lulus, Politeknik Penerbangan Makassar mempunyai tugas untuk tetap memonitor keberadaan alumni, karena hal tersebut akan dapat menjadi umpan balik bagi Politeknik Penerbangan Makassar untuk mengevaluasi kebijakan penyelenggaraan pendidikan. Program untuk menunjang hal tersebut adalah penyelenggaran System Tracer Alumni.

System ini memanfaatkan teknologi SMS sehingga memberikan kemudahan kepada alumni untuk mengaksesnya. Mekanisme Tracer adalah sebagai berikut : Data Alumni direcord termasuk nomor handphone, SMS Gateway for Alumni akan melakukan distribusi jika ada informasi penting dan Alumni diharapkan mengirim balikan informasi menggunakan handphone tentang keadaan dirinya, apakah sudah bekerja ? apakah sedang mencari? Apakah sedang mengembangkan bisnis?
Dengan adanya informasi dari alumni, Politeknik Penerbangan Makassar akan selalu mengetahui gambaran lulusannya. Setiap ada perubahan, alumni dihimbau untuk menginformasikannya ke SMS Gateway for Alumni.

\section{KESIMPULAN}

Kesimpulan penelitian berdasar pada tujuan penelitian, dapat dikemukakan sebagai berikut :

1. Aspek input:

Proses penerimaan sipencatar masih perlu dibenahi terutama dalam hal transparansi mekanisme persayaratan calon taruna. Serta konsistensi implementor pelaksana penerimaan sipencatar pada Politeknik Penerbangan Makassar.

Kuota calon taruna pada Politeknik Penerbangan Makassar khususnya untuk program studi manajemen lalu lintas udara perlu untuk ditingkatkan sesuai tingkat kebutuhan di beberapa Bandar Udara di Indonesia.

2. Aspek Transformasi:

Pembelajaran pada program studi manajemen lalu lintas udara Politeknik Penerbangan Makassar, terkhusus pada mata kuliah Approach Control Service (APP) dan Aerodrome Control Service (Tower) baik pada teori maupun praktek masih perlu untuk ditingkatkan. Begitupula terhadap evaluasi dosen Politeknik Penerbangan Makassar harus senantiasa berkomitmen untuk senantiasa melakukan peningkatan pendidikan dosen di masa yang akan datang secara berkelanjutan dengan mempertimbangkan kembali proporsi dosen terhadap jumlah taruna serta kualitas dosen yang tidak hanya didasarkan pada pendidikan formalnya saja namun perlu untuk di evaluasi kembali mengenai kapasitas nya dalam melaksanakan kegiatan belajar mengajar.

\section{Aspek Output}

Pada dasarnya kualitas pada Politeknik Penerbangan Makassar khususnya pada program studi manajemen lalu lintas udara sudah cukup baik. Hanya saja jumlah lulusannya masih dianggap kurang. Sehingga kedepan, Poltekbang Makassar bersama BPSDM Kementrian Perhubungan Udara dapat melakukan peningkatan jumlah taruna 
sebagaimana dengan mempertimbangkan tingkat kebutuhan oleh para users.

\section{SARAN}

1. Perlunya peningkatan jumlah calon taruna dan fasilitas belajar pada Politeknik Penerbangan Makassar.

2. Perlunya intensifikasi evaluasi kapasitas dosen serta penambahan jumlah dosen sesuai dengan proporsi peningkatan jumlah taruna.

3. Pembelajaran masih perlu ditingkatkan baik pada teori dan praktek terutama sekaitan dengan materi Aerodrome Control Service (Tower).

\section{Ucapan Terima Kasih}

Tidak lupa saya ucapkan banyak Terima kasih kepada Politeknik Penerbangan Makassar yang telah mendanai penelitian ini.

\section{DAFTAR PUSTAKA}

Arikunto Suharsimi (2012) Dasar Dasar Evaluasi Pendidikan (Edisi Revisi). Jakarta: Bumi Aksara

Engoswara. (1987). Administrasi Pendidikan, Jakarta: P2LPTK

Jalal, Fasli dan Dedi Supriadi. (2001). Reformasi Pendidikan Dalam Konteks Otonomi Daerah, Yogyakarta: Adicita Karya Nusa.

Nana Syaodih Sukmadinata. (2005). Pengembangan kurikulum Bandung: Remaja Rosdakarya

Nawawi. (1989). Administrasi Pendidikan, jakarta. Haji Masagung

Nazir. M.P.D. (2005). Metode Penelitian. Ghalia Indonesia. Bogor

Purwadi. (2003). Pelayanan profesional kurikulum 2004 pengelolaan Kurikulum di tingkat sekolah / Departemen Pendidikan Nasional RI--Jakarta: Depdiknas

Riduwan. (2009) Metode dan Teknik Menyusun Proposal Penelitian. Jakarta: Alfabeta

Sugiyono. (2008). Metode Penelitian Bisnis. Bandung: Alfabeta.
Suwandi. (1999). Model Evaluasi Kurikulum, Penerapannya pada Kurikulum Muatan Lokal", Jurnal Pendidikan dan KebudayaanNo. 19 tahun ke-5 Oktober 1999. Jakarta: Depdikbud.

Tilaar, H.A.R Nugroho R. (2008). Kebijkan Pendidikan: Pengantar Untuk Memahami kebijakan Pendidikan dan Kebijakan Pendidikan Sebagai kebijakan Publik. Yogyakarta: Pustaka Belajar 